- 3 технічного креслення;

- $\quad$ охорони праці і техніки безпеки;

- 3 математики.

2. Показати вміння і навички:

- застосовування знань для виконання практичних завдань;

- виконання побудови різних діаграм;

- здійснення математичних розрахунків;

- володіння виробничими прийомами оброблення різних матеріалів під час виготовлення виробів;

- аналізувати зв'язок між основними економічними показниками підприємницької діяльності;

- обирати схеми погашення боргу по кредитах, необхідним для здійснення підприємницької діяльності, заснованої на виготовленні реальних виробів масового використання в житті.

За результатами вивчення теоретичних модулів i виконання усіх практичних завдань студент одержує залік.

\title{
Література
}

1. Жиляев И.Б. Первые шаги в бизнесе / И. Жиляев, А. Щур. - К. : Либра, 1994. - 85 с.

2. Замков О.О. Математические методы в экономике / Замков О.О., Толстопятенко А.В., Черемных Ю.Н. - М. : Дис, 1998. - 327 с.

3. Четыркин Е.М. Финансовая математика / Евгений Михайлович Четыркин. - М. : Дело, 2000. - 428 с.

Стаття надійшла до редакції 01.06.2012 p.

УДК 371.134:6(07)

\author{
C. I. Ткачук, \\ докторант, \\ Уманський ДПУ, \\ імені Павла Тичини
}

\section{ОСОБЛИВОСТІ ФОРМУВАННЯ ТЕХНОЛОГІЧНОЇ КУЛЬТУРИ МАЙБУТНЬОГО ВЧИТЕЛЯ ТРУДОВОГО НАВЧАННЯ}

\footnotetext{
Ткачук С.І. Особливості формування технологічної культури майбутнього вчителя трудового навчання.

У статті розкрито проблеми та особливості формування технологічної культури майбутніх учителів трудового навчання в прочесі підготовки їх у вищому навчальному закладі. Проаналізовано практичний складник технологічної культури майбутнього вчителя трудового навчання.

Ключові слова: освітня галузь «Технологія», учитель трудового навчання, технологічна культура, професійно педагогічна культура, педагогічні технології.

Ткачук С. И. Особенности формирования технологической культуры будущих учителей трудового обучения.

В статье раскрываются проблемы и особенности формирования технологической культуры будущих учителей трудового обучения в прочессе подготовки их в высшем учебном заведении. Анализируется практическая составляющая технологической культуры будущего учителя трудового обучения.

Ключевые слова: образовательная область «Технология», учитель трудового обучения, технологическая культура, профессионально-педагогическая культура, педагогические технологии.
} 
Tkachuk S. Features of technological education future teacher employment training

In this article the problem of the formation and characteristics of technological culture of future teachers in preparing them in high school. We analyze the practical component of technological culture of the future teacher employment training.

Key words: educational sector "Technology" teacher labor training, technological culture, professional and pedagogical culture, educational technology.

Збереження європейського культурного багатства i мовної різноманітності має грунтуватися на культурній спадщині різних традицій. Європа завжди була різноманітною щодо культури і мов, однак іiі майбутнє залежить від спроможності організувати те цінне розмаїття так ефективно, щоб мати позитивні результати. Нагальній потребі взаємного пізнання i взаємодії різних культур за побудови єдиної Європи багато уваги приділено у Великій хартії університетів, які втілюють традиції європейської культури в галузі освіти. Проте, як стверджує В. Межуєв, культура - це не тільки важливе наукове поняття, без якого не може обійтися жодна галузь суспільно-теоретичного знання, а й реальна проблема сучасного історичного розвитку, що вимагає практичного розв’язання на всіх рівнях [5].

Одним із пріоритетних завдань сучасного національного виховання $€$ підготовка особистості з високим рівнем культури праці. Виконання цього завдання традиційно покладають на освітню систему України та підготовку кваліфікованих педагогів. Подальша демократизація системи освіти, іiі гуманізація, здійснення особистісно зорієнтованого підходу до учня зумовлюють істотні зміни освітніх пріоритетів і висувають принципово нові вимоги до професійно-педагогічної підготовки вчителя.

Фахова досконалість сучасного вчителя все більше характеризується рівнем його педагогічної культури, що визначає ефективність педагогічних дій. Однак проблеми культури праці взагалі, а педагогічної зокрема, мало досліджені, а педагоги-практики не мають необхідних рекомендацій.

Певні напрацювання 3 окресленої проблеми $\epsilon$ у дослідженнях науковців, які досліджували феномен культури. А. Бистрота, К. Іванова, В. Лихвар, С. Подольська та інші визначають, що культура - це інтегративне утворення, яке поєднує сукупність матеріальних і духовних видів культур та приводять основні змістовні характеристики й визначення цим культурам.

Д. Бенкс, Р. Гарсія, К. Ірвін, М. Красовицький, В. Кузьменко у своїх дослідженнях розглядали питання полікультурності. Р. Гуревич розкриває поняття інформаційної культури, О. Пономарьов розглядає педагогічні технології формування професійної культури. Водночас мало хто звертає увагу на формування культури виробничих процесів. Культура виробництва виникає у взаємодії робітника з технікою (технічні відносини) та виробничими відносинами між людьми. Ядром культури виробництва $\epsilon$ сама технікотехнологічна праця. Нові технології вимагають і зумовлюють не тільки наявність достатнього рівня знань (практичних і теоретичних) i виробничих навиків, а й високого рівня особистісних якостей робітника: трудова допитливість, творчий підхід до справи, постійне удосконалення техніки, «ноу-хау» тощо. 
Кожен із складників культури виробництва відіграє значну роль у процесі виробництва. Культура виробничого технологічного процесу передбачає технічній рівень виробництва, техніко-технологічні уміння i навички людини, наукову організацію праці, технологічні виробничі відносини та інше, а вчителю окрім цих знань необхідно також оволодіння технологією педагогічного процесу.

Технологічна культура як складник професійності вчителя віддзеркалює його здатність приймати рішення та діяти відповідно до особливостей застосування сучасних педагогічних та інформаційних технологій.

У сучасних психолого-педагогічних дослідженнях приділяється значна увага вдосконаленню технологій навчання майбутнього вчителя (В. Бондар, О. Мороз, О. Савченко, Т. Яценко та інші), формуванню професійної культури майбутнього вчителя та окремих ii складників (В.Гриньова, Т. Іванова, Н. Крилова, Н. Морзе, В. Семиченко, Л. Столяревська). Однак технологічна культура вчителя не знайшла достатнього вивчення у психолого-педагогічних дослідженнях. Передовсім науково не обгрунтовані саме поняття, зміст, система і чинники формування технологічної культури майбутніх учителів у процесі професійно-педагогічної підготовки.

В умовах формування інформаційно-технологічного суспільства та підготовки вчителя нової генерації особливого значення набуває проблема технологічної культури вчителя інформатики.

Визначення культури як специфічного способу людської діяльності лягло в основу так званого діяльнісного підходу, прихильниками якого стали В. Давидович, Ю. Вишневський, В. Жариков, Ю. Жданов, Н. Злобін, М. Коган, Е. Маркарян, О. Ханова, 3. Хелус та інші.

У сучасному пізнанні поняття діяльності відіграє центральну, методологічну роль, оскільки саме за його допомогою надається універсальна характеристика людського світу. Саме через призму принципу діяльності, на думку Е. Юдіна, відкривається цілісний спосіб бачення тієї чи іншої соціальної реальності і створюється можливість узагальненого пояснення різних соціальних явищ 3 однієї теоретичної позиції. Дослідник називає діяльність «універсальним пояснювальним принципом», який поєднує емпіричну достовірність 3 теоретичною і методологічною конструктивністю [1].

У педагогіці вищої школи внесок у розроблення культурологічних засад, змісту і технологій педагогічної освіти зробили С. Архангельський, А. Вербицький, І. Ісаєв, В. Леднєв, В. Лозова, Г. Троцко, А. Маркова, М. Нікандров, С. Павлютенков, В. Сластьонін, В. Слободчиков.

Питання підготовки вчителя трудового навчання розглянуті у працях науковців-педагогів П. Атутова, С. Батишева, Ю. Васильєва, Й. Гушулея, О. Коберника, В. Кузьменка, Г. Левченка, В. Сидоренка, А. Терещука, Г. Терещука, Д. Тхоржевського та інших.

Кардинальні зміни, що відбуваються нині в шкільній освітній галузі «Технологія», висувають високі вимоги до особистісних та професійних 
якостей вчителя трудового навчання. Актуальними для нього стають внутрішня технологічна культура, широка технічна ерудиція, технічний світогляд, активність, ініціативність, самостійність, прагнення до творчості, висока відповідальність. Цілком очевидно, що наведені якості повинні грунтуватися на глибокій професійній компетентності вчителя, яка в свою чергу може бути забезпечена лише на основі формування в нього фундаментальних знань та широти його підготовки.

Таке твердження не випадкове, оскільки одним із пріоритетних напрямків розвитку вищої освіти в усьому світі $\epsilon$ фундаменталізація професійної підготовки. Саме фундаменталізація освіти покликана забезпечити професійну мобільність сучасного фахівця, що стає все більш актуальною в умовах зростаючої конкуренції на ринку праці. Принцип мобільності передбачає широту підготовки вчителя, його готовність до стрімких змін у змісті навчання, здатності швидко переорієнтуватися на викладання будь-якого нового профілю трудового навчання в старшій школі. У цих умовах традиційні навчальні предмети типу інженерних дисциплін не виправдовують свого призначення в підготовці вчителя трудового навчання для оновленої шкільної освітньої галузі.

3 огляду на культурологічну парадигму особливого значення набуває проблема формування технологічної культури, яка, на думку вчених, визначає світогляд і саморозуміння людини та суспільства [1].

В. Лола зазначав, що технологічна культура - це культура XXI століття i вона $\epsilon$ четвертим етапом універсальної культури (після міфологічної, космологічної та антропологічної), оскільки людство живе в умовах, коли відходить до минулого індустріальний етап науково-технічного прогресу 3 його екстенсивною «ідеологією» (за будь-яку ціну домогтися максимального результату), а новий (технологічний) етап визначає пріоритет способу над результатом діяльності, зважаючи на іï соціальні, економічні, психологічні, естетичні та інші чинники. Очевидно, що саме вчителю трудового навчання належить розв'язувати це складне й важливе завдання: здійснювати формування технологічної культури підростаючого покоління. Тому підготовка вчителів трудового навчання потребує особливої уваги формуванню технологічної культури студентів факультетів, що готують майбутніх фахівців освітньої галузі «Технологія». Оволодіння технологічною культурою майбутніми учителями трудового навчання в соціальному й особистісному напрямах запорука їх професіоналізму й активної життєвої позиції, здатності зробити свій внесок у соціальне становлення підростаючого покоління.

Отже, здійснений аналіз структурних компонентів ППК (аксіологічний, технологічний, творчий) дозволив з'ясувати, що технологічна культура $\epsilon$ складовим елементом професійно-педагогічної культури вчителя трудового навчання, необхідним компонентом творчої самореалізації та професійного самовдосконалення особистості фахівця, глибокого володіння основами перетворювальної діяльності, готовності до інновацій і новаторства. Вона передбачає наявність у людини системи технологічних знань, умінь, особистісних якостей та практичної підготовки до трудової діяльності в сучасних умовах соціально-економічного розвитку суспільства. 
Кожна людина має вміти, спираючись на наукові знання, комплексно підходити до вибору способів своєї діяльності та оцінювання її результатів. Способи діяльності становлять культури. Отже, технологічну культуру можна вважати одним із типів універсальної культури.

Якщо розглядати технологічну культуру в соціально-культурному розрізі, iї треба сприймати як узагальнення - універсальну культуру. Вона характеризує сучасну історичну епоху, сучасне технологічне суспільство, визначається рівнем розвитку наукових знань, технічних засобів і різних видів технологій матеріального й духовного виробництва, змістом суспільного життя та перетворювальної діяльності людей, зразків поведінки, мислення і світогляду. Технологічна культура - створене самою людиною сучасне штучне середовище існування й самореалізації, джерело регулювання соціальної взаємодії та поводження з людьми і природою.

У звичному, вузькому плані технологічна культура - це рівень оволодіння людиною формами, способами професійної, соціокультурної діяльності та свідомого підпорядкування ціннісним соціокультурним пріоритетам; рівень оволодіння загальними формами реалізації мистецтва планування, прогнозування, творення, виконання й оформлення.

Технологічна культура, як одна з універсальних культур, фундаментальних складових загальної та професійної культур, впливає на все життя людини та суспільства. По-перше, вона передбачає наявність у людини системи технологічних знань, умінь і технологічно важливих якостей. По-друге, технологічна культура формує певний технологічний погляд на світ i виявляється в технічному світогляді, в основі якого лежить глобальний планетарний погляд на світ, що є поєднанням біосфери, техносфери та ноосфери. Центром цієї системи $є$ людина, яка своїм розумом свідомо підтримує рівновагу у світі.

Технологічна культура має гносеологічні наслідки і впливає на спосіб та характер мислення людини. Тобто складовою частиною технологічної культури є технологічне мислення - мисленнєва здатність людини до перетворювальної діяльності щодо створення матеріальних і духовних цінностей для блага людини, суспільства, природного середовища, узагальнене опосередковане віддзеркалення індивідом науковотехнологічної сфери. Технологічне мислення спрямоване на пошук оптимальних засобів перетворення речовини, енергії й інформації на необхідний для людини продукт. У ньому вирізняються такі особливості:

- спрямування не стільки на пізнання оточення, скільки на зміну його в інтересах людини;

- змінюються функції знань, які повинні мати комплексний характер і містити гностичний, пошуковий i перетворювальний аспекти, сприяти відкриттю ще не пізнаних об'єктів і процесів;

- провідне місце посідають методи і засоби (технології) засвоєння нового матеріалу; 
- тісно пов'язане 3 рефлексією, вмінням створювати образ оптимального кінцевого результату;

- $є$ проектним і становить процес узагальненого й опосередкованого пізнання дійсності, під час якого людина застосовує технологічні, технічні, економічні та інші знання у процесі виконання проектів створення товарів або послуг від ідеї до їі реалізації, тобто покликане активізувати проектну діяльність людини;

- спрямоване в майбутнє, виникає «час-свідомість». Це зумовлює необхідність постійного зростання рівня технологічної культури людини, а разом і відповідальності кожного за сьогодення та майбутнє.

В умовах постійного втручання людини у розвиток природних i соціальних процесів нового звучання набувають питання етики, відбувається процес формування нової техноетики.

Етичні уявлення сучасної людини сягають у попередню антропологічну культуру i тепер вже не відповідні вимогам сучасності. Уявлення про волю, відповідальність, незалежність особистості тощо треба переглянути. Але це відбувається повільно, а нові проблеми виникають швидше. Досі природу, живу і неживу, вважають лише джерелом продуктів і сировини, які споживаються або переробляються людиною. Окремі компоненти не сприймаються як етичні партнери. Через те, що етична ситуація - породження технологічної культури - радикально вирізняється серед інших, необхідно говорити не просто про етику, а про техноетику та практичну діяльність особистості, зокрема, педагогічну.

А отже, активне застосування в усіх галузях виробництва техніки, технологій повною мірою змінило не лише характер трудової діяльності людини, а й відповідні вимоги до іiі практичної підготовки, які нерозривно пов'язані з технологічною культурою вчителя.

Практична діяльність в межах професії становить один із складників всієї практичної освіти як частина освіти взагалі. Інакше кажучи, сутність практичної педагогічної діяльності визначається, по-перше, тим, що водночас це одна 3 основних частин практичної підготовки як цілісної системи, яка має в освіті особистості відносну автономність і свій базовий предмет - формування вмінь в галузі освоюваних людиною видів діяльності, в тому числі і технологічної.

Основою технологічної культури є перетворювальна діяльність, відповідно практична діяльність у будь-яких конкретних галузях є насамперед засобом формування життєво важливих, соціально значущих, технологічних умінь і навичок, які необхідні людині протягом усього життя: уміння вчитися, приймати рішення і нести відповідальність, планувати і організовувати свою роботу і роботу інших і т.д. Формування наведених умінь здійснюється під час практичної підготовки у вищих навчальних закладах.

Зазначимо, що формування культури, в тому числі (технологічної) можливе тільки на основі зв'язку навчання 3 практикою. Саме практична педагогічна діяльність становить засіб оволодіння майбутнім учителем 
трудового навчання технологічними вміннями i навичками, прийомами педагогічної роботи.

Технологічна підготовка студентів створює найкращі умови для формування таких елементів практичної складової технологічної культури, як уміння та навички, оскільки вона є практичною (предметною) основою застосування загальнонаукових знань, закріплення загально трудових i спеціальних умінь, вироблення практичних навичок діяльності у матеріальному виробництві. Адже результатом практичної діяльності є створення матеріальних благ. Технології тільки «народжуються» в практичній діяльності педагогів.

Формування практичного складової технологічної культури студентів передбачається у процесі вивчення таких навчальних теоретичних i практичних дисциплін, практик:

- «Використання сучасних інформаційних та комунікативних технологій у навчальному процесі»;

- «Теорія і методика навчання технологій»;

- «Практикум в навчальних майстернях»;

- проблемні групи;

- курсові та випускні кваліфікаційні роботи;

- педагогічна та технологічна практики;

- самостійна та гурткова робота студентів.

Практичний складник формування технологічної культури має базуватися як на стандартних формах організації навчального процесу, так із використанням інноваційних форм, а саме: аудиторної (лекції, лабораторнопрактичні та семінарські заняття, практичні заняття в навчальних майстернях); самостійної роботи (реферати, курсові та випускні кваліфікаційні та магістерські роботи). Поряд 3 традиційними методами навчання використовуємо метод проектів, ділові ігри, презентації та ін. Функція самостійної роботи полягає в навчанні студентів умінню отримувати і відбирати факти, робити власні узагальнення, висновки, давати пояснення, використовувати i викладати набуті знання. Вона готує майбутнього вчителя до безперервної освіти, добування нової інформації протягом всієї його професійної діяльності.

Практичний складник технологічної культури пов’язана 3 розв’язанням завдань підготовки вчителів до майбутньої практичної професійної діяльності в новому інформаційно-технологічному суспільстві, освоєнням сучасної техніки, технологій, комп'ютерної грамотності, формуванням професійної орієнтації. Завершеність процесу практичної діяльності визначається досягнутим результатом.

Окреслені проблеми вимагають грунтовного вдосконалення системи підготовки майбутнього вчителя трудового навчання.

Для забезпечення належної підготовки необхідно:

- вдосконалити програми вивчення техніко-технологічних дисциплін, для забезпечення системності та послідовності отримання технічних знань (переглянути навчальні плани підготовки студентів спеціальності 
«Технологічна освіта» та зменшити кількість годин на вивчення дисциплін суто інженерного профілю);

- в програму підготовки добавити дисципліни, спрямовані на методичну підготовку студентів до вивчення 3 учнями технікотехнологічних основ сучасного виробництва.

Отже, технологічна культура як складовий елемент професійної підготовки майбутнього вчителя трудового навчання - необхідний компонент творчої самореалізації та професійного самовдосконалення особистості майбутнього фахівця, глибокого та грамотного оволодіння основами освітньої діяльності, готовності до інновацій і новаторства.

Отже, особливості змісту формування технологічної культури майбутніх фахівців освітньої галузі «Технологія» має визначатися на засадах професійно-культурологічного підходу, який відображає особливості i функції педагогічної діяльності і спрямований на формування системи узагальнених професійно-технологічних знань, умінь і навичок, розвиток технологічного мислення.

\section{Література}

1. Александрова М.В. Культура та цивілізація: становлення проблематики в українській філософській думці (кінець XIX - початок XX століть): 17.00.01 - автореф. дис. канд. пед.н. - М.В. Александрова. - Харків, 2003. - 17 с.

2. Державний стандарт освітньої галузі «Технологія» // Трудова підготовка в закладах освіти. - 2003. - №1. - С. 3-6.

3. Ільченко А. Актуальні питання трудового i профільного навчання та професійної підготовки / А. Ільченко // Трудова підготовка в закладах освіти. - 2002. №1. - C. i-17.

2. Клепко С.Ф. Сума технологій для всіх Українців / С.Ф. Клепко // Імідж сучасного педагога. - 2006. - №8. - С.12-15.

3. Межуев В.М. Культура и история / В.М. Межуев. - М. : Политиздат, 1977. - 199 с. Стаття надійшла до редакції 01.06.2012 р.

\section{ФІЛОСОФСЬКО-МЕТОДОЛОГІЧНІ ПЕРЕДУМОВИ СТАНОВЛЕННЯ ТЕОРІЇ ПРОЕКТУВАННЯ ПЕДАГОГІЧНИХ СИСТЕМ}

\footnotetext{
Авраменко О.Б. Філософсько-методологічні передумови становлення теорії проектування педагогічних систем.

У статті здійснено історичний, філософсько-методологічний аналіз становлення теорії проектування педагогічних систем та системного підходу як один із головних напрямків методології спеиіального наукового пізнання, мета і завдання якого полягають у дослідженнях певних об'єктів як складних систем.

Ключові слова: проектування, педагогічне проектування, система, системний підхід, система «техносвіт - технологічна освіта».
} 